\title{
Current PCR-based methods for the detection of mycotoxigenic fungi in complex food and feed matrices
}

\author{
H. Ur Rahman ${ }^{1,2,3}$, X. Yue ${ }^{1,2,4}$, Q. Yu1, ${ }^{1,2,3,5}$, W. Zhang ${ }^{1,2,6}, Q_{\text {. Zhang }}^{1,2,4^{*}}$ and P. Li $\mathbf{i}^{1,2,3,4,5,6^{*}}$ \\ ${ }^{1}$ Oil Crops Research Institute, Chinese Academy of Agricultural Sciences, Wuhan 430062, China P.R.; ${ }^{2}$ Key Laboratory of \\ Biology and Genetic Improvement of Oil Crops, Ministry of Agriculture, Wuhan 430062, China P.R.; ${ }^{3}$ Key Laboratory of \\ Detection for Mycotoxins, Ministry of Agriculture, Wuhan 430062, China P.R.; ${ }^{4}$ Laboratory of Quality \& Safety Risk Assessment \\ for Oilseeds Products, Wuhan, Ministry of Agriculture, Wuhan 430062, China P.R.; ${ }^{5}$ National Reference Laboratory for \\ Agricultural Testing (Biotoxin), Wuhan 430062, China P.R.; ${ }^{6}$ Quality Inspection and Test Center for Oilseeds Products, \\ Ministry of Agriculture, Wuhan 430062, China P.R.; zhangqi01@caas.cn; peiwuli@oilcrops.cn
}

Received: 24 April 2019 / Accepted: 6 July 2019

(c) 2019 Wageningen Academic Publishers

\section{OPEN ACCESS (c) (1) (2) REVIEW ARTICLE}

\begin{abstract}
Mycotoxins are toxic secondary fungal metabolites produced by certain types of filamentous fungi, such as Aspergillus, Fusarium, and Penicillium spp. Mycotoxigenic fungi and their produced mycotoxins are considered to be an important issue in food and feed safety due to their toxic effects like carcinogenicity, immunosuppression, neurotoxicity, nephrotoxicity, and hepatotoxicity on humans and animals. To boost the safety level of food and feedstuff, detection and identification of toxins are essential at critical control points across food and feed chains. Zero-tolerance policies by the European Union and other organizations about the extreme low level of tolerance of mycotoxins contamination in food and feed matrices have led to an increasing interest to design more sensitive, specific, rapid, cost-effective, and safer to use mycotoxigenic fungi detection technologies. Hence, many mycotoxigenic fungi detection technologies have been applied to measure and control toxins contamination in food and feed substrates. PCR-based mycotoxigenic fungi detection technologies, such as conventional PCR, real-time PCR, nested PCR, reverse transcriptase (RT)-PCR, loop-mediated isothermal amplification (LAMP), in situ PCR, polymerase chain reaction-denaturing gradient gel electrophoresis (PCR DGGE), co-operational PCR, multiplex PCR, DNA arrays, magnetic capture-hybridization ( $\mathrm{MCH}$ )-PCR and restriction fragment length polymorphism (RFLP), would contribute to our understanding about different mycotoxigenic fungi detection approaches and will enhance our capability about mycotoxigenic fungi identification, isolation and characterization at critical control points across food and feed chains. We have assessed the principles, results, the limit of detection, and application of these PCR-based detection technologies to alleviate mycotoxins contamination problem in complex food and feed substrates. The potential application of these detection technologies can reduce mycotoxins in complex food and feed matrices.
\end{abstract}

Keywords: mycotoxigenic fungi, mycotoxins, food safety, detection technologies, PCR

\section{Introduction}

Mycotoxins are toxic secondary metabolites produced by certain types of filamentous fungi or moulds (Zain, 2011). The very well-known fungal species involved in the contamination of complex food and feed matrices belong to genera Aspergillus, Penicillium, Fusarium, and Alternaria (Bennett and Klich, 2003). Pereira et al. (2014) reported that over 300 mycotoxins have been identified.
However, those mycotoxins which are regularly involved in the contamination of complex food and feed matrices are aflatoxins (AF), ochratoxins (OT), fumonisins, patulin (PAT), zearalenone (ZEA), and trichothecenes (TCTC), including deoxynivalenol (DON). Iqbal et al. (2015) reported that Aspergillus species mostly produce AF, ZEA, DON and fumonisins are produced by Fusarium species, while Penicillium species produce PAT. Negedu et al. (2011) reported that unwanted fungal growth and contamination of 
foodstuff by mycotoxins becomes a significant problem. The presence of dangerous mycotoxins in food and feed matrices represents a severe threat to human and animal health, hampers international trading, causes losses of food and feedstuffs, divert resources towards research, enforcement, regulation, and poses relevant research challenges in the field of food and feed toxicology (Bennett and Klich, 2003; Stoev, 2013). Upadhaya et al. (2010) reported that according to the FAO, about $25 \%$ of the world's food crops are contaminated by mycotoxins, such as in maize, wheat, sorghum, rice, soybeans, peanuts, oats, cottonseed, and other food and feed crops (Alshannaq and $\mathrm{Yu}, 2017$ ). Due to the consumption of mycotoxin-contaminated feed, animal originated food like meat, eggs, milk, and milk products were also contaminated (Bennett and Klich, 2003; Richard, 2007). Aflatoxin contaminated milk can cause stunted growth in children, fumonisins cause esophageal cancer, and ochratoxin can induce kidney diseases (Raiola et al., 2015). Wu et al. (2014) reported that prolonged DON exposure could cause immunotoxicity. Mycotoxigenic fungi and their produced mycotoxins, concerning human and animal health are shown in Table 1.

To find mycotoxin contamination in food and feed matrices, a proper test of the commodities is required. Due to the diverse distribution of mycotoxins in food and feed matrices, appropriate sampling techniques are pre-requisite for gaining reliable results (Turner et al., 2015). Because of the importance and special interest in the field of food and feed contamination by mycotoxins, preventive methods have been established and developed to reduce the exposure of mycotoxins. Turner et al. (2015) reported that in the 1970s and 1980s when antibodies were developed for the detection of major mycotoxins. As a result, the use of enzyme-linked immunosorbent assay (ELISA) increased. With the period of time, chromatographic techniques for mycotoxins detection were constantly developed and improved (Eshelli et al., 2018). Chromatographic technologies include highperformance liquid chromatography (HPLC) coupled with ultraviolet (UV), mass spectrometry (MS), fluorescence (FLD), detectors for detection of mycotoxins, such as AF, ZEA, OT, fumonisins, and DON (Shephard, 2016). At present, among the chromatographic mycotoxin detection technologies, liquid chromatography-mass spectrometry (LC-MS) techniques are widely used than gas chromatography-mass spectrometry (GC-MS). Most MS methods use chromatographic separation with HPLC or ultra-high performance liquid chromatography (UHPLC). Mostly UHPLC is used for multi-mycotoxin analysis due to their higher resolution and sensitivity as compared with HPLC (Pereira et al., 2014). Gas chromatography (GC) technique is commonly used for the detection of TCTC toxins with MS detectors because it allows the simultaneous identification and quantification of compounds. Although chromatographic technology has a lot of advantages due to the requirement of skills and instrumentation, the technique remains as laboratory-based.

Somashekar et al. (2004) reported that PCR-based detection of mycotoxigenic fungi targeting the fungal DNA (Figure 1 ) is considered a good alternative to previous developed mycotoxigenic fungi detection technologies for rapid identification, because of the high sensitivity and specificity. Niessen (2007) reported that mycotoxigenic fungi detection technologies based on the specific DNA sequences amplification are easy to use, safe to use, rapid, sensitive, and capable of replacing the conventional mycotoxigenic fungi detection technologies. Yamashita et al. (2018) developed a PCR-based method for the detection and identification of amplification products from Talaromyces macrosporus and Talaromyces trachyspermus using primer sets that target the isocitrate lyase gene. PCR-based technologies make it

Table 1. List of mycotoxins, mycotoxigenic fungi and effects on health.

\begin{tabular}{|c|c|c|c|}
\hline Mycotoxins & Mycotoxigenic fungi & Health implications & References \\
\hline \multirow[t]{2}{*}{ Aflatoxins } & $\begin{array}{l}\text { Aspergillus flavus } \\
\text { Aspergillus parasiticus }\end{array}$ & & \\
\hline & Aspergillus nomius & liver cirrhosis, immunosuppressive & Reiter et al., 2009; Streit et al., 2012 \\
\hline \multirow[t]{2}{*}{ Ochratoxin A } & $\begin{array}{l}\text { Aspergillus niger } \\
\text { Aspergillus ochraceus }\end{array}$ & $\begin{array}{l}\text { human carcinogen } \\
\text { kidney lesions }\end{array}$ & \\
\hline & Penicillium verrucosum & urothelial tumors & Anli and Alkis, 2010 \\
\hline \multirow[t]{2}{*}{ Fumonisins } & Fusarium verticillioides & & \\
\hline & Fusarium proliferatum & esophageal cancer & Chain et al., 2018 \\
\hline \multirow[t]{3}{*}{ Patulin } & Penicillium expansum & & \\
\hline & Penicillium claviforme & gastrointestinal, neurological & \\
\hline & Penicillium patulum & disorders & Zhong et al., 2018; loi et al., 2017 \\
\hline \multirow[t]{2}{*}{ Zearalenone } & Fusarium culmorum & & \\
\hline & Fusarium graminearum & infertility, early pubertal changes & Ashiq, 2015 \\
\hline Deoxynivalenol & Fusarium graminearum & diarrhoea, vomiting, gastroenteritis & EFSA, 2013 \\
\hline
\end{tabular}


A

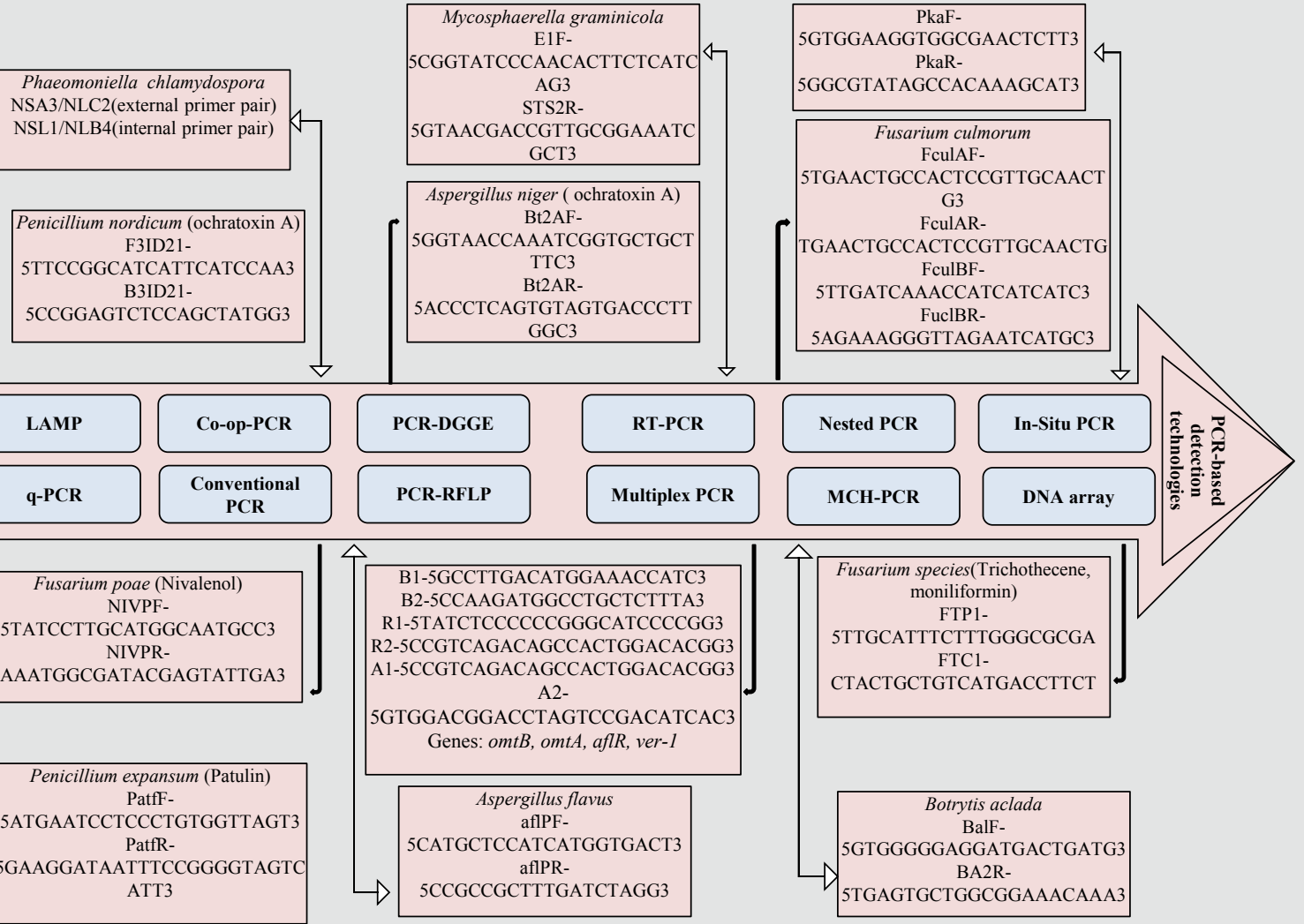

B

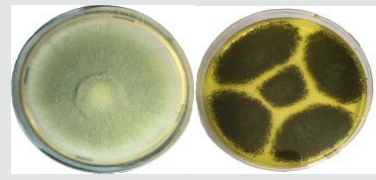

DNA extraction

Fungal isolates

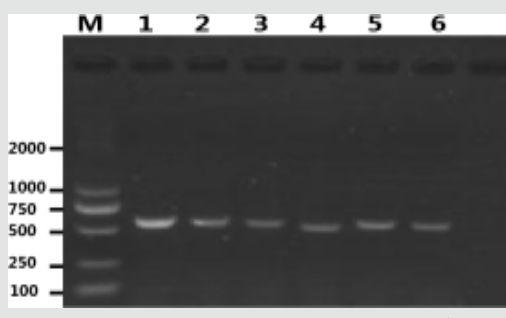

Master mix

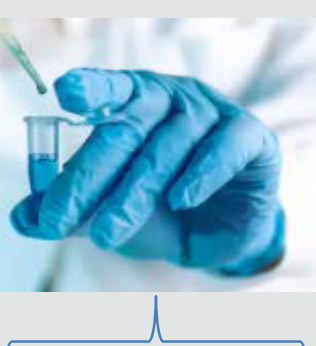

Gel electrophoresis

PCR procedure:

Denaturation: $94^{\circ} \mathrm{C}$

for $15-30$ seconds

Annealing: $54-60^{\circ} \mathrm{C}$

for 20-40 seconds

Extension: $72-80^{\circ} \mathrm{C}$

for 3 minutes
Master mix

contains:

Reaction buffer

dNTPs

$\mathrm{MgCl} 2$

Forward Primer

Reverse Primer

Taq polymerase

RNase-free water

$\square$ Add master mix (50 or $25 \mu \mathrm{l}$ ).

Add template DNA $(2 \mu 1)$.

Figure 1. (A) Schematic view of PCR-based detection technologies along with genes targeted as sequence source. (B) General detection mechanism procedure. 
possible the rapid sorting of commodities based on fungal content thus can be used as a useful tool to reduce the exposure of food and feed matrices to mycotoxins (Niessen, 2007; Ramakrishna et al., 2012). The basic principle of PCR based mycotoxigenic fungi detection technologies is to develop primer targeting the genes involved in the mycotoxin biosynthesis. For the detection of mycotoxigenic fungi and mycotoxins numerous technologies exist; detection technologies that are based on DNA sequenced amplification includes PCR, real-time PCR, nested PCR, RT-PCR, LAMP, in situ PCR, PCR-DGGE, co-operational PCR, multiplex PCR, DNA arrays, MCH-PCR and PCRRFLP (Edwards et al., 2002; Elizaquível et al., 2014). The objectives of this study to highlights the principles, results, and application of these PCR-based mycotoxigenic fungi detection technologies in complex food and feed matrices, which will facilitate future research to provide baseline information.

\section{Conventional PCR}

Discussion upon mycotoxins issue has reached its paroxysm since these toxic secondary fungal metabolites are found in the majority of food and feed matrices. Using rapid, sensitive, specific, and safe to use technologies to prevent the food and feed chain from mycotoxigenic fungi before reaching the unacceptable level or at very early stages is the demand of the day. Molecular technique such as PCR ensures rapid detection of fungal contamination in complex food and feed matrices as compared to conventional, laborious, time consuming microbiological analysis. PCR technology can amplify specific DNA sequences exponentially by in vitro DNA synthesis. The effectiveness of PCR-based detection is based on its specific in vitro amplification of DNA targets from trace complex substrates, due to its high level of specificity and sensitivity: Currently, the PCR-based assays are the preferred choice for detecting mycotoxigenic fungi. In PCR-based detection assays, the most important variable is primer design, a suitable set of primers to specifically amplify the target sequence need to fulfill a range of requirements, such as GC content (40$60 \%$ ), $\mathrm{T}_{\mathrm{m}}$ values (between 50 and $80^{\circ} \mathrm{C}$ ), $5^{\prime}$-end stability, 3 '-end specificity and minimum primer-primer interaction and hairpins in primers, etc. Specific primers are derived from amplified/cloned DNA or RNA sequences from the target pathogen species. Stackebrandt et al. (1992) reported that in the case of molecular detection, ribosomal genes and spacers between them are a good choice of targets, because of high copy number in the genome and having variable and conserved sequences. Universal primers, based on conserved sequences, can be used to amplify and sequence these targets. The non-transcribe spacer (NTS) and intergenic spacer (IGS) regions also contain highly variable sequences among closely related species. Primers based on the internal transcribed spacer (ITS) regions are commonly used to detect mycotoxigenic fungi.
Both ITS1 and ITS2 regions can be amplified, depending upon primer pairs. Specific primers have been developed from conserved sequences for a variety of mycotoxigenic fungi. The best way to develop species-specific primers is by using computer software programs (Primer2, PrimerQuest, etc.) once the sequences of target rDNA are compared with related fungal species by online alignment program. The beauty of using primer designing software is that they take into account a range of requirements in primer designing. Some unidentified unique DNA regions are also used to develop species-specific primers. In this case, random amplified polymorphic DNA (RAPD) markers are applied to compare target organisms with non-target ones, bands specific to the target organisms were detected and cloned. To check for the presence of similar DNA sequences in the associated species, bands which are unique and specific to the target organisms are used as a probe. The use of these sensitive PCR based assays allows the researchers to identify the contamination of mycotoxigenic fungi in complex food and feed matrices and to define the potential risk for human and animal health. Dinolfo et al. (2012) developed a PCR method to detect potential nivalenol (NIV) producing Fusarium poae isolates based on tri7 genespecific primer pair (NivPF, NivPR). In this experiment, 125 Fusarium poae isolates and 18 other Fusarium species were investigated, and only Fusarium poae isolates gave positive results for the presence of tri7 DNA fragment, demonstrating that this PCR assay is a rapid, sensitive and reliable. Information about limit of detection (LOD), principles, results, application, and species detected of the PCR-based detection technologies are shown in Table 2.

\section{Real-time PCR}

Real-time PCR monitors the amplification process of targeted DNA molecules in real time, rather than at its end, as is the case with conventional PCR. Real-time PCR detects amplicons with specific fluorescent signals, eliminating the post-amplification processing steps required by conventional PCR, resulting in a significant reduction in time. Schena et al. (2004) reported that real-time PCR is a useful technique for sensitive, accurate, and high throughput target DNA quantification. Two types of real-time PCR methods are used to detect mycotoxigenic fungi: sequence non-specific and specific according to the chemistry used in PCR. In the case of sequence non-specific methods, dyes like SYBER Green 1 are used that emit fluorescent light when interjected into double-stranded DNA whereas in case of sequence-specific methods generally TaqMan or scorpion sequence-specific fluorescent probe is used. The fluorescent signal is produced by a specific hybridisation between the probe and the target DNA sequence, which guarantees higher specificity than DNA binding dyes (SYBER Green I) and enables the discrimination of single base pair mismatches. Tannous et al. (2015) applied qPCR technology for the precise identification and quantification 
Table 2. List of current toxigenic fungi detection methods, principles, results, limit of detection (LOD), species detected and application.

\begin{tabular}{|c|c|c|c|c|c|c|}
\hline $\begin{array}{l}\text { Detection } \\
\text { methods }\end{array}$ & Principles & Results & LOD & $\begin{array}{l}\text { Species/toxin } \\
\text { detected }\end{array}$ & $\begin{array}{l}\text { Application } \\
\text { of assay }\end{array}$ & References \\
\hline $\begin{array}{l}\text { Conventional } \\
\text { PCR }\end{array}$ & $\begin{array}{l}\text { Fungal isolates DNA extraction and sequencing of the } \\
\text { amplified products. PCR, nivalenol, and deoxynivalenol } \\
\text { HPLC/FD analysis. }\end{array}$ & $\begin{array}{l}\text { This method develops a rapid and reliable PCR assay to } \\
\text { detect potential nivalenol-producing Fusarium poae isolates. }\end{array}$ & $10 \mathrm{fg} \mathrm{DNA} / \mu \mathrm{l}$ & $\begin{array}{l}\text { Fusarium poae } \\
\text { (nivalenol) }\end{array}$ & $\begin{array}{l}\text { barley and } \\
\text { wheat }\end{array}$ & $\begin{array}{l}\text { Chaumpluk } \\
\text { et al., } 2016\end{array}$ \\
\hline Real-time PCR & $\begin{array}{l}\text { Artificial contamination, incubation and DNA isolation from } \\
\text { apple sample, Specific qPCR primer designing and internal } \\
\text { amplification control design. Real-time PCR development } \\
\text { and optimisation. Extraction and analysis of patulin in } \\
\text { samples. Statistical analysis. }\end{array}$ & $\begin{array}{l}\text { This work offers to prevent toxin production in fruits during } \\
\text { the storage period, and this assay can be easily applied } \\
\text { during the industrial production of different apple byproducts. }\end{array}$ & $0.04 \mu \mathrm{g} / \mathrm{ml}$ & $\begin{array}{l}\text { Penicillium } \\
\text { expansum (patulin) }\end{array}$ & apple & $\begin{array}{l}\text { Tannous et } \\
\text { al., } 2015\end{array}$ \\
\hline Nested PCR & $\begin{array}{l}\text { Fungal isolates and plant material, DNA extraction, DNA } \\
\text { cloning, sequencing, and primer designing. Polymerase } \\
\text { chain reaction, sensitivity tests, and results. }\end{array}$ & $\begin{array}{l}\text { Sensitive involves a low risk of cross contaminations } \\
\text { between samples, low costs and reduced hands-on time as } \\
\text { compared to standard nested-PCR protocols. }\end{array}$ & $\begin{array}{l}5-50 \mathrm{fg} \text { (purified } \\
\text { target DNA) }\end{array}$ & $\begin{array}{l}\text { Fusarium } \\
\text { culmorum (DON. } \\
\text { trichothecenes) }\end{array}$ & cereals & $\begin{array}{l}\text { Klemsdal } \\
\text { and Elen, } \\
2006\end{array}$ \\
\hline RT-PCR & $\begin{array}{l}\text { Fungal species and isolates, inoculated wheat plants and } \\
\text { field samples, RNA extraction, Northern hybridization: one- } \\
\text { step RT-PCR, Two-step RT-PCR, and results. }\end{array}$ & $\begin{array}{l}\text { This method detects and identifies fungal pathogens in } \\
\text { plants thus more accurately represent the situation of living } \\
\text { pathogen population than those obtained by PCR. }\end{array}$ & $100 \mathrm{pg}$ total RNA & $\begin{array}{l}\text { Mycosphaerella } \\
\text { graminicola }\end{array}$ & wheat & $\begin{array}{l}\text { Guo et al., } \\
2005\end{array}$ \\
\hline LAMP & $\begin{array}{l}\text { Fungal strain selection. Extraction of DNA. Designing of } \\
\text { primers. LAMP reaction }\end{array}$ & $\begin{array}{l}\text { The LAMP assay combined with rapid DNA extraction } \\
\text { method providing an alternative rapid, specific and sensitive } \\
\text { DNA-base method suitable for application directly on site } \\
\text { notably in key steps of dry-cured meat production. }\end{array}$ & $\begin{array}{l}10^{2} \text { conidia/ } \\
\text { reaction }\end{array}$ & $\begin{array}{l}\text { Penicillium nordicum } \\
\text { (ochratoxin A) }\end{array}$ & $\begin{array}{l}\text { dry-cured } \\
\text { meat } \\
\text { products }\end{array}$ & $\begin{array}{l}\text { Ferrara et al. } \\
2015\end{array}$ \\
\hline In situ PCR & $\begin{array}{l}\text { Mildew spores and mycelia, Genomic DNA extraction, and } \\
\text { then PCR. Placement of conidia on in situ PCR slides, and } \\
\text { then the microscope. }\end{array}$ & $\begin{array}{l}\text { This technique allows positive confirmation of the origin of } \\
\text { genes cloned from obligate pathogenic fungi and could be } \\
\text { adapted for use on any samples containing mixed fungal } \\
\text { species. }\end{array}$ & & Blumeria graminis & barley & $\begin{array}{l}\text { Bindslev et } \\
\text { al., } 2002\end{array}$ \\
\hline PCR-DGGE & $\begin{array}{l}\text { Grapes sampling, incubation, and genomic DNA extraction. } \\
\text { PCR implication, DGGE, gel analysis, and gel bands } \\
\text { excision and sequencing. }\end{array}$ & $\begin{array}{l}\text { PCR-DGGE represents a useful tool to compare } \\
\text { environmental samples for the study of the dynamics of } \\
\text { fungal communities, but comigrations represent a limit in its } \\
\text { use to describe the species present. }\end{array}$ & & $\begin{array}{l}\text { Aspergillus niger } \\
\text { (ochratoxin A) }\end{array}$ & $\begin{array}{l}\text { wine, dairy } \\
\text { products, } \\
\text { meat }\end{array}$ & $\begin{array}{l}\text { Laforgue et } \\
\text { al., 2009b }\end{array}$ \\
\hline $\begin{array}{l}\text { Co-operational } \\
\text { PCR }\end{array}$ & $\begin{array}{l}\text { Fungal species, isolates, DNA extraction, sequencing and } \\
\text { preparation of the specific probe. Co-PCR amplification, dot } \\
\text { blot hybridisation, and colorimetric detection. Comparative } \\
\text { sensitivity between Co-PCR and single PCR. Validation of } \\
\text { the technique using artificially inoculated grapevine cuttings. }\end{array}$ & $\begin{array}{l}\text { Co-operational PCR is } 100 \text { times more sensitive than a } \\
\text { single PCR using the primer pair ITS1F-ITS4 and was only } \\
\text { slightly less sensitive than the nested PCR technique. }\end{array}$ & $0.1 \mathrm{pg}$ & $\begin{array}{l}\text { Phaeomoniella } \\
\text { chlamydospora }\end{array}$ & grapevine & $\begin{array}{l}\text { Martos et al., } \\
2010\end{array}$ \\
\hline Multiplex PCR & $\begin{array}{l}\text { Collection of aflatoxin producing and non-producing } \\
\text { fungal strain. Culture the selected strain. Examine the } \\
\text { aflatoxigenicity through AVM and TLC. Preparation of } \\
\text { primers. amplification through PCR. }\end{array}$ & $\begin{array}{l}\text { Multiplex PCR method may provide accurate and specific } \\
\text { detection of aflatoxigenic Aspergillus species in fermented } \\
\text { soybean foods }\end{array}$ & $125 \mathrm{pg} / \mu \mathrm{l}$ & $\begin{array}{l}\text { Aspergillus flavus } \\
\text { (aflatoxins } G_{1} \text { ) }\end{array}$ & $\begin{array}{l}\text { fermented } \\
\text { soybean } \\
\text { foods }\end{array}$ & $\begin{array}{l}\text { Kim et al., } \\
2011\end{array}$ \\
\hline
\end{tabular}




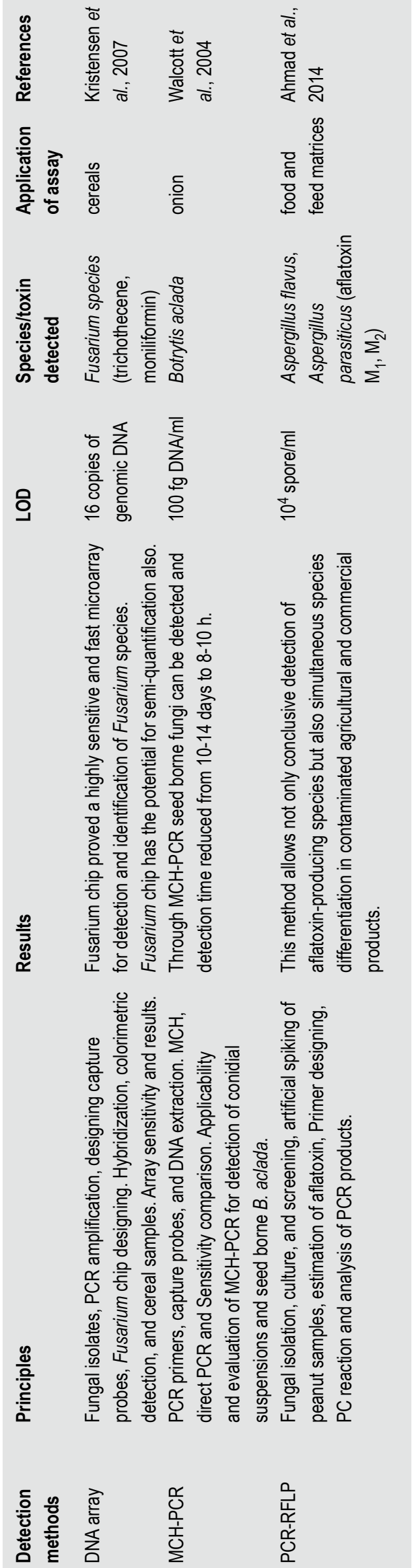

of Penicillium expansum, which is commonly known for the production of PAT toxins when infecting the apples. Primer pair (patFF, patFR) were developed targeting patF gene involved in the biosynthesis of PAT toxins. The qPCR detection technology did not show any effectiveness when directly applied to the food and feed due to the complex nature of the substrate (Rossen et al., 1992).

\section{Nested-PCR}

The nested PCR approach was developed to improve the sensitivity and specificity of the mycotoxigenic fungi detection technologies. Porter-Jordan et al. (1990) reported that in the nested PCR approach, the external primer pair amplifies a large amplicon which is used as a template for internal primer pair. Thus this approach consists of two consecutive amplification reactions. These two consecutive reactions can be done in a single closed tube supporting high output as long as the internal primer pair annealing temperature is higher than the external primer pair so as a result at the initial stage of amplification the internal primer pair will not bind. Klemsdal and Elen (2006) applied a nested-PCR approach to detect Fusarium culmorum in cereal-based crop using a single closed tube. Concentrations of the external primer pair (FculAF, FculAR) was diluted 10,000 times compared to the internal primer pair (FculBF, FculBR) concentration. Results of the experiment showed that 5-50 fg was the limit of detection of the target DNA and allowed detection $1 \%$ infected wheat seed from the mixture. This study defines the Fusarium culmorum detection in cereal samples by this sensitive nested-PCR method in a single closed tube, which has a low risk of crosscontamination between samples and is cost-effective, and approximately 100 times more sensitive than the previous PCR methods.

\section{RT-PCR}

Differentiation between living and dead fungi is a big limitation in PCR-based assays. Reverse transcriptase (RT)PCR was developed to address this issue as it detects the target mRNA. Sheridan et al. (1998) reported that RT-PCR is a suitable and accurate technique and can considerably differentiate living fungi from the dead one as mRNA is quickly degraded in dead cells. mRNA is reverse transcribed by reverse transcriptase to produce stable cDNA for use as templates in any PCR-based techniques. RT-PCR is highly sensitive and specific enough to detect pathogens in a plant that are naturally infected and artificially inoculated. Guo et al. (2005) successfully applied RT-PCR to assess the development of disease in naturally infected and artificially inoculated plants. In this study, primer pairs (E1-F, STS2-R), which were initially designed for PCR amplification of $\beta$-tubulin genes (Fraaije et al., 1999), were found that these primer pairs were also appropriate for RT-PCR. RT-PCR is highly sensitive and specific enough 
to detect pathogens in plants that are naturally infected and artificially inoculated. Martin et al. (2000) reported that the most essential thing for practical identification is the sensitivity of the assay. For PCR amplification, two-step RT-PCR reaction conditions are more suitable, and results show that the total RNA detection of two-step RT-PCR is fifty times more sensitive than one-step RT-PCR. However, the two-step RT-PCR is more expensive and laborious. Because of RT-PCR, it is possible to indirectly quantify the biomass of Mycosphaerella graminicola in wheat plants (Guo et al., 2005).

\section{LAMP (loop-mediated isothermal amplification)}

LAMP is a highly sensitive nucleic acid amplification technique that can amplify a few copies to a tremendous amount of target DNA in less than an hour. The LAMP reaction is processed at a constant temperature by Bst DNA polymerase enzymes with a set of four specially designed primers that identify six areas on the target DNA, and as a result, the specificity and sensitivity are much higher (Tomita et al., 2008). Special attention needs to be paid on the annealing step to ensure a successful LAMP assay because four primers are used in LAMP assay rather than two primers used in conventional PCR, which makes the annealing step very critical. Among the four primers, two primers are used as inner while the other two are used as outer primers in LAMP assay. In the initial steps of the LAMP assay, all four primers were used, and only the inner primers were added in later steps. Tomita et al. (2008) reported that temperature values of the outer primers must be lower than those of the inner primers to assure the early synthesis of the inner amplicon. The concentration of the inner primers should also be higher than that of the outer primers. Parida et al. (2008), Cardoso et al. (2010), Kuan et al. (2010) reported that LAMP assay had been extensively used for the detection of numerous humans, animal, and plant pathogens. Targeting the gene directly involved in mycotoxins biosynthesis is better because it is more likely to be related to potential toxigenicity. Ferrara et al. (2015) applied LAMP assay for the rapid detection of Penicillium nordicum which allowed the researchers to identify mycotoxin contamination directly on-site in complex food and feed production chains. Targeting the key gene responsible for the biosynthesis of OTA in Penicillium nordicum, four primers, two outer primers (F3-1D21, B31D21) and two inner primers (FIP-1D21, BIP-1D21) were designed. Susca et al. (2014) reported that some fungal strains were incapable of producing mycotoxins due to the absence of biosynthetic clusters. That's why non-OTA Penicillium nordicum strains generate negative LAMP assay (Denschlag et al., 2014). Ferrara et al. (2015) investigated a key gene for OTA biosynthesis in Penicillium nordicum as a LAMP assay target. A trace amount of DNA added in LAMP master mix to generate an ample amount of target DNA to determine the Penicillium nordicum without fungal isolation. As the LAMP assay identifies Penicillium nordicum in artificially contaminated salami indicates that it is also possible to directly detect mycotoxigenic fungi on the surface of dry-cured meat. The big advantage of the LAMP assay is that it can be applied directly on-site in the dry-cured meat industry to ensure food safety and quality.

\section{In situ PCR}

The amplification of DNA samples from raw material is subject to misinterpretation if more than one species is present. To overcome this problem, in situ PCR technology has been developed, which combines molecular biology techniques, PCR, and in situ hybridisation techniques to amplify specific gene sequences in complete cells or tissues (Long, 1998). In situ hybridisation has become a common laboratory technique used for the analysis of gene expression and the localisation of specific DNA and RNA molecules in cells (Chu et al., 2019). The in situ PCR can detect low-copy DNA or RNA and made accurate positioning in morphology (Zhao et al., 2009). Bindslev et al. (2002) designed an in situ PCR technique that links PCR amplification to the light microscopic image, so the amplified tissue is stained, thus confirming which morphotype has been amplified and then the PCR product can be sequenced. The developed technique was applied on fixed Blumeria graminis spores, and mycelia using primers (PkaF, PkaR) derived from the sequence of the gene encoding the catalytic subunit of protein kinase A ( $b k a 1)$. To confirm the source of amplified genes, the use of in situ PCR is the most suitable technique. The in situ PCR technology is capable of detecting and identifying uncultivable fungi from soil, infected plant, medical, and veterinary samples.

\section{PCR-DGGE}

The grape surface is frequently contaminated by some species of mycotoxin producing filamentous fungi that have negative impacts on the product produced from grapes, like wine (Cabañes et al., 2002). Laforgue et al. (2009) applied the PCR-DGGE method to establish a fungal community profile from grapes, to monitor fungi potentially involved in wine contamination. DNA from the fungi first amplified using PCR is then exposed to DGGE. Myers et al. (1985) reported that in the DGGE assay, urea was used as a chemical denaturing agent to dissociate double strand DNA before separation acrylamide gels. Sequence variations of specific fragments migrate at different rates, allowing for sensitive detection. Laforgue et al. (2009) applied the PCR-DGGE technique to the grape samples; several bands were unrecorded in the reference database, showing an incomplete knowledge of the fungal grape community. As a result, we can conclude that the PCR-DGGE technique is a handy tool to profile fungal communities, but is unsuitable to describe precisely the species present. 


\section{Co-operational PCR}

A co-operational PCR was developed based on the simultaneous action of four primers and ten times less reagents usage than conventional PCR (Olmos et al., 2002). Olmos et al. (2002) observed that four amplicons were produced through a combination of two primer pairs, producing as large a fragment as possible through the cooperational action of the amplifier. The sensitivity and specificity of the nested PCR can be improved through co-operational PCR. In co-operational and nested PCR assays the external primer pairs are used for general amplification, while the internal primer pairs are used for specific amplification. The specificity and sensitivity of the co-operational PCR are usually improved by coupling with dot blot hybridisation and a specific probe. Martos et al. (2010) applied co-operational PCR coupled with dot blot hybridization and posterior colorimetric visualisation for the detection of Phaeomoniella chlamydospora, one of the most important fungi involved in grapevine disease. The ITS region was amplified through co-operational PCR for Phaeomoniella chlamydospora and 17 other fungi involved in grapevine diseases using external (NSA3/ NLC2) and internal (NSI1/NLB4) primer pairs. Specific probe (Pch2D) was designed targeting the ITS2 region of the rDNA to detect the Phaeomoniella chlamydospora. The specific probe only hybridizes with DNA amplicons of Phaeomoniella chlamydospora isolates, verifying the specific detection of the fungus while the other 17 fungal species show negative results for the specific probe.

\section{Multiplex PCR}

In multiplex PCR assay, several species-specific primers are combined in a single PCR tube to detect various mycotoxigenic fungi simultaneously, and the amplified products are determined through gel electrophoreses. Priyanka et al. (2015) developed a multiplex PCR assay for the simultaneous detection of five major metabolic pathway genes, namely, aflr (aflatoxin), pks (ochratoxin A), tri5 (trichothecene), pks13 (zearalenone) and fum 13 (fumonisin), producing Aspergillus, Penicillium and Fusarium species. Rashmi et al. (2013) developed a rapid multiplex PCR assay for the simultaneous specific and sensitive detection of four major mycotoxin metabolic pathway genes, viz. nor 1 (aflatoxin), Tri6 (trichothecene), fum13 (fumonisin) and otanps (ochratoxin A). Kim et al. (2011) applied the multiplex PCR for the detection of aflatoxigenic Aspergillus species in meju, aflatoxin producing (KCCM 60330, 35078) and nonaflatoxin producing (KCCM 60130, 34792) Aspergillus stains were selected. To amplify the genes (omtB, omtA, aflR, and ver-1) related to aflatoxin biosynthesis, two sets of three primers were designed for the detection of aflatoxigenic fungi in this study. Primer set I (omtB-1,2, aflR-1,2, and omtA-1,2) used in this study is a new combination of primers while primer set II (aflR-1,2, ver-1-F, R, and omtA-1,2) used to amplify genes was used previously (Del Fiore et al., 2010). The use of several target genes in multiplex PCR assay can overcome the false positive, and a false negative problem that occurs due to the high homology between the genes of aflatoxin and non-aflatoxin-producing Aspergillus species. The results of the multiplex PCR assay showed a positive correlation between the presence of aflatoxin biosynthesis genes analyzed by multiplex PCR and aflatoxin production determined by high-performance liquid chromatography (HPLC) and thin-layer chromatography (TLC). It reveals that multiplex PCR assay gives precise and specific detection of aflatoxigenic Aspergillus species.

\section{DNA array}

Lievens et al. (2005) reported that to study gene expression or develop SNP profiles, DNA array has been developed that can be used to detect a large number of organisms at the same time. Detection arrays are usually made up of discrete positioned species-specific detector sequences that are fixed on nylon filters or glass slide for macro or microarray, respectively. For signal amplification, in general, the target DNA is amplified by primers, and the target area of the primer consists of a specific sequence of species, which is marked at the same time or subsequently. Kristensen et al. (2007) reported that single PCR is capable of discriminating a large number of organisms, depending on the full discriminatory potential that exists in the area targeted. Kristensen et al. (2007) applied a diagnostic microarray-based chip for the identification of Fusarium species. Compared to a conventional Fusarium species detection technique, the PCR and microarray combination provides an easy to use, safe, fast, and cost-effective detection technique in food and feed matrices. To detect and identify 14 trichothecenes and moniliformin-producing Fusarium species, the DNA microarray was established and based on the recent phylogenetic analyses of translation elongation factor-1 alpha sequences capture probes were developed. During the development of capture probes, special emphasis was put on corresponding to species specifically involved in mycotoxin synthesis abilities. After the PCR amplification of a part of the translation elongation factor- 1 alpha followed by hybridization to the Fusarium chip, the results were visualised by a colorimetric silver quant detection method. In this study, the developed Fusarium chip was validated against the five naturally infested cereal samples, and the results showed that the Fusarium chip is a valuable tool for screening cereal samples in food and feed production chain.

\section{MCH (magnetic capture-hybridization)-PCR}

Jacobsen, in 1995, developed the MCH-PCR technique to reduce the effects of inhibitors and non-target DNA during the PCR amplification. The primary steps like DNA 
extraction and purification combine in $\mathrm{MCH}$, including hybridisation with a single-stranded DNA probe on magnetic beads and a subsequent PCR amplification step of the extracted gene. Jacobsen (1995) reported that in this innovative process, beads coated with paramagnetic streptavidin conjugate with biotin-labeled oligonucleotide probe used for capturing single-stranded target DNA from crude DNA preparations. Species-specific primers are used for PCR amplification after $\mathrm{MCH}$ thus enhance the efficiency of target DNA isolation. Walcott et al. (2004) applied empirically determined parameters for the development of MCH-PCR to detect Botrytis aclada from onion seed, which provide a starting point from which this technique can be improved. MCH-PCR proved to be an efficient technique by which Botrytis aclada DNA could be detected in onion seed. MCH-PCR is based on unique nucleotide sequences; it eliminates the need to distinguish between Botrytis aclada and other Botrytis spp. based on morphological characteristics. Conventional PCR yielded the expected 413 bp DNA fragment from aqueous Botrytis aclada DNA solutions with one $\mathrm{ng} / \mathrm{ml}$ and $100 \mathrm{pg} / \mathrm{ml}$. These correspond to detection thresholds of $10 \mathrm{pg} / \mathrm{PCR}$ reaction and $1 \mathrm{pg} / \mathrm{PCR}$ reaction. $\mathrm{PCR}$ primers $(\mathrm{Ba} 1, \mathrm{Ba} 2)$ were designed based on a DNA fragment generated by universally primed PCR. MCH-PCR established a detection threshold of $100 \mathrm{fg} / \mathrm{ml}$ of Botrytis aclada DNA, which represented a 10 -fold increase in sensitivity over direct PCR. MCH-PCR requires technical expertise and specific reagents and equipment; however, the data indicate a significant potential benefit to employing this assay.

\section{PCR-RFLP (restriction fragment length polymorphism)}

Generally, RFLP of PCR products used for distinguishing mycotoxigenic fungi after detection (El Khoury et al., 2011). Ahmad et al. (2014) develop specific PCR protocol to detect the aflatoxin producing fungi and to discriminate the closely related Aspergillus flavus and Aspergillus parasiticus species in complex food and feed matrices normally contaminated by aflatoxins. In this study, exonic regions of aflp gene were targeted for developing the specific primer pairs, after designing the primer pairs the specificity of the designed primer pairs were analysed on aflatoxin and non-aflatoxinproducing Aspergillus species using conventional PCR. When the designed primers are used for other mycotoxins producing species, no amplification was observed showing the specificity of designed primers for amplification of aflp gene fragment only. This method can be applied to discriminate the aflatoxigenic fungi at the species level, maintaining their specificity, accuracy, and sensitivity.

\section{Conclusions and future outlooks}

Numerous diagnostic PCR-based technologies are now available to detect mycotoxigenic fungi in complex food and feed matrices. Compared to other conventional methods of fungal identification, PCR-based detection technologies are more accurate, sensitive, rapid, cost-effective, safe to use, and portable to detect toxigenic fungi in food and feed matrices. PCR-based detection technologies developed during the last decade targets the genes involved in the mycotoxins biosynthesis; these targeted genes are used as a sequence source to design species-specific primers. Biosynthesis of most mycotoxins is a complex process; it is highly influenced by a wide range of factors including fungal species potentials, duration of fungal growth, moisture content, temperature, storage conditions, water stress, and insect pests attack can also enhance mycotoxins production (Ashiq, 2015). Here a question arises that PCRbased detection technology that mostly targets the genes involved in mycotoxins biosynthesis is the technology of choice? To detect the contaminants, it is needed to find a positive correlation between amplification signal and mycotoxin concentration (Niessen, 2007). Keeping in mind the simultaneous detection of mycotoxigenic fungi, many researchers developed PCR-based detection technologies which are not only rapid, sensitive, accurate but also costeffective. The information provided in this review about the PCR-based identification of mycotoxigenic fungi can play a vital role in the field of food and feed quality control because the technologies have the potential to detect the contaminants in food and feed matrices successfully. Due to the implementation of the strict rules and regulation by different countries about the toxins levels in food and feed matrices, it is necessary to develop such type of techniques which have on-site toxins detection ability maintaining their sensitivity and specificity. Future mycotoxigenic fungi detection technologies should focus on nanoparticle and chips technologies and should be equally available to each part of this world.

\section{Conflict of interests}

The authors declare no competing and conflict of interest

\section{Acknowledgements}

This work was supported by the International Science \& Technology Cooperation Program of China (2017YFC1601205), Natural Science Foundation of China (31701726), Agricultural Science and Technology Innovation Program of CAAS (CAAS-XTCX2019024) and The Major Project of Hubei Provincial Technical Innovation (2018ABA081). 


\section{References}

Ahmad, M.M., Ahmad, M., Ali, A., Hamid, R., Javed, S. and Abdin, M.Z., 2014. Detection of Aspergillus flavus and Aspergillus parasiticus from aflatoxin-contaminated peanuts and their differentiation using PCR-RFLP. Annals of Microbiology 64: 1597-1605. https:// doi.org/10.1007/s13213-014-0803-5

Alshannaq, A. and Yu, J.-H., 2017. Occurrence, toxicity, and analysis of major mycotoxins in food. International Journal of Environmental Research and Public Health 14: 632.

Anli, E. and Alkis, İ.M., 2010. Ochratoxin A and brewing technology: a review. Journal of the Institute of Brewing 116: 23-32. https://doi. org/10.1002/j.2050-0416.2010.tb00394.x

Ashiq, S., 2015. Natural occurrence of mycotoxins in food and feed: Pakistan perspective. Comprehensive Reviews in Food Science and Food Safety 14: 159-175. https://doi.org/10.1111/1541-4337.12122 Bennett, J.W. and Klich, M., 2003. Mycotoxins. Clinical Microbiology Reviews 16: 497-516. https://doi.org/10.1128/CMR.16.3.497516.2003

Bindslev, L., Oliver, R.P. and Johansen, B., 2002. In situ PCR for detection and identification of fungal species. Mycological Research 106: 277-279. https://doi.org/10.1017/S0953756202005646

Cabañes, F.J., Accensi, F., Bragulat, M.R., Abarca, M.L., Castellá, G., Minguez, S. and Pons, A., 2002. What is the source of ochratoxin A in wine? International Journal of Food Microbiology 79: 213-215. https://doi.org/10.1016/S0168-1605(02)00087-9

Cardoso, T.C., Ferrari, H.F., Bregano, L.C., Silva-Frade, C., Rosa, A.C.G. and Andrade, A.L., 2010. Visual detection of turkey coronavirus RNA in tissues and feces by reverse-transcription loop-mediated isothermal amplification (RT-LAMP) with hydroxynaphthol blue dye. Molecular and Cellular Probes 24: 415-417. https://doi. org/10.1016/j.mcp.2010.08.003

Chain, E., Panel o.C.i.t.F., Knutsen, H.-K., Alexander, J., Barregård, L., Bignami, M., Brüschweiler, B., Ceccatelli, S., Cottrill, B., Dinovi, M., Edler, L., Grasl-Kraupp, B., Hogstrand, C., Hoogenboom, L., Nebbia, C.S., Petersen, A., Rose, M., Roudot, A.-C., Schwerdtle, T., Vleminckx, C., Vollmer, G., Wallace, H., Dall'Asta, C., Eriksen, G.S., Taranu, I., Altieri, A., Roldán-Torres, R. and Oswald, I.P., 2018. Risks for animal health related to the presence of fumonisins, their modified forms and hidden forms in feed. EFSA Journal 16: e05242. https://doi.org/10.2903/j.efsa.2018.5242

Chaumpluk, P., Plubcharoensook, P. and Prasongsuk, S., 2016. Rapid detection of aflatoxigenic Aspergillus sp. in herbal specimens by a simple, bendable, paper-based lab-on-a-chip. Biotechnology Journal 11: 768-779. https://doi.org/10.1002/biot.201500435

Chu, Y.-H., Hardin, H., Zhang, R., Guo, Z. and Lloyd, R.V., in press. In situ hybridization: introduction to techniques, applications and pitfalls in the performance and interpretation of assays. Seminars in Diagnostic Pathology. 36: 336-341. https://doi.org/10.1053/j. semdp.2019.06.004

Del Fiore, A., Reverberi, M., Ricelli, A., Pinzari, F., Serranti, S., Fabbri, A.A., Bonifazi, G. and Fanelli, C., 2010. Early detection of toxigenic fungi on maize by hyperspectral imaging analysis. International Journal of Food Microbiology 144: 64-71. https://doi.org/10.1016/j. ijfoodmicro.2010.08.001
Denschlag, C., Rieder, J., Vogel, R.F. and Niessen, L., 2014. Real-time loop-mediated isothermal amplification (LAMP) assay for group specific detection of important trichothecene producing Fusarium species in wheat. International Journal of Food Microbiology 177: 117-127. https://doi.org/10.1016/j.ijfoodmicro.2014.02.010

Dinolfo, M., Barros, G. and Stenglein, S., 2012. Development of a PCR assay to detect the potential production of nivalenol in Fusarium poae. FEMS Microbiology Letters 332: 99-104. https:// doi.org/10.1111/j.1574-6968.2012.02581.x

Edwards, S.G., O'Callaghan, J. and Dobson, A.D.W., 2002. PCRbased detection and quantification of mycotoxigenic fungi. Mycological Research 106: 1005-1025. https://doi.org/10.1017/ S0953756202006354

European Food Safety Authority (EFSA), 2013. Deoxynivalenol in food and feed: occurrence and exposure. EFSA Journal 11: 3379. https://doi.org/10.2903/j.efsa.2013.3379

El Khoury, A., Atoui, A., Rizk, T., Lteif, R., Kallassy, M. and Lebrihi, A., 2011. Differentiation between Aspergillus flavus and Aspergillus parasiticus from pure culture and aflatoxin-contaminated grapes using PCR-RFLP analysis of aflR-aflJ intergenic spacer. Journal of Food Science 76: M247-M253. https://doi.org/10.1111/j.17503841.2011.02153.x

Elizaquível, P., Aznar, R. and Sánchez, G., 2014. Recent developments in the use of viability dyes and quantitative PCR in the food microbiology field. Journal of Applied Microbiology 116: 1-13. https://doi.org/10.1111/jam.12365

Eshelli, M., Qader, M., Jambi, E., Hursthouse, A. and Rateb, M., 2018. Current status and future opportunities of omics tools in mycotoxin research. Toxins 10: 433. https://doi.org/10.3390/toxins10110433

Ferrara, M., Perrone, G., Gallo, A., Epifani, F., Visconti, A. and Susca, A., 2015. Development of loop-mediated isothermal amplification (LAMP) assay for the rapid detection of Penicillium nordicum in drycured meat products. International Journal of Food Microbiology 202: 42-47. https://doi.org/10.1016/j.ijfoodmicro.2015.02.021

Fraaije, B.A., Lovell, D.J., Rohel, E.A. and Hollomon, D.W., 1999. Rapid detection and diagnosis of Septoria tritici epidemics in wheat using a polymerase chain reaction/PicoGreen assay. Journal of Applied Microbiology 86: 701-708. https://doi.org/10.1046/j.13652672.1999.00716.x

Guo, J.-R., Schnieder, F., Beyer, M. and Verreet, J.-A., 2005. Rapid detection of Mycosphaerella graminicola in wheat using reverse transcription-PCR assay. Journal of Phytopathology 153: 674-679. https://doi.org/10.1111/j.1439-0434.2005.01035.x

Ioi, D.J., Zhou, T., Tsao, R. and F. Marcone, M., 2017. Mitigation of patulin in fresh and processed foods and beverages. Toxins 9: 157. https://doi.org/10.3390/toxins9050157

Iqbal, S., Jinap, S., Abbasi Pirouz, A. and Abdull Razis, A.F., 2015. Aflatoxin $M_{1}$ in milk and dairy products, occurrence and recent challenges: a review. Trends in Food Science and Technology 46: 110-119. https://doi.org/10.1016/j.tifs.2015.08.005

Jacobsen, C.S., 1995. Microscale detection of specific bacterial DNA in soil with a magnetic capture-hybridization and PCR amplification assay. Applied and Environmental Microbiology 61: 3347-3352. 
Kim, D.M., Chung, S.H. and Chun, H.S., 2011. Multiplex PCR assay for the detection of aflatoxigenic and non-aflatoxigenic fungi in meju, a Korean fermented soybean food starter. Food Microbiology 28: 1402-1408. https://doi.org/10.1016/j.fm.2011.06.017

Klemsdal, S.S. and Elen, O., 2006. Development of a highly sensitive nested-PCR method using a single closed tube for detection of Fusarium culmorum in cereal samples. Letters in Applied Microbiology 42: 544-548. https://doi.org/10.1111/j.1472765X.2006.01880.x

Kristensen, R., Gauthier, G., Berdal, K.G., Hamels, S., Remacle, J. and Holst-Jensen, A., 2007. DNA microarray to detect and identify trichothecene- and moniliformin-producing Fusarium species. Journal of Applied Microbiology 102: 1060-1070. https://doi. org/10.1111/j.1365-2672.2006.03165.x

Kuan, C.-P., Wu, M.-T., Lu, Y.-L. and Huang, H.-C., 2010. Rapid detection of squash leaf curl virus by loop-mediated isothermal amplification. Journal of Virological Methods 169: 61-65. https:// doi.org/10.1016/j.jviromet.2010.06.017

Laforgue, R., Guérin, L., Pernelle, J.J., Monnet, C., Dupont, J. and Bouix, M., 2009. Evaluation of PCR-DGGE methodology to monitor fungal communities on grapes. Journal of Applied Microbiology 107: 1208-1218. https://doi.org/10.1111/j.1365-2672.2009.04309.x Lievens, B., Brouwer, M., Vanachter, A.C.R.C., Lévesque, C.A., Cammue, B.P.A. and Thomma, B.P.H.J., 2005. Quantitative assessment of phytopathogenic fungi in various substrates using a DNA macroarray. Environmental Microbiology 7: 1698-1710. https://doi.org/10.1111/j.1462-2920.2005.00816.x

Long, A.A., 1998. In situ polymerase chain reaction: foundation of the technology and today's options. European Journal of Histochemistry 42: 101-109.

Martin, R.R., James, D. and Lévesque, C.A., 2000. Impacts of molecular diagnostic technologies on plant disease management. Annual Review of Phytopathology 38: 207-239. https://doi.org/10.1146/ annurev.phyto.38.1.207

Martos, S., Torres, E., El Bakali, M.A., Raposo, R., Gramaje, D., Armengol, J. and Luque, J., 2010. Co-operational PCR Coupled with dot blot hybridization for the detection of Phaeomoniella chlamydospora on infected grapevine wood. Journal of Phytopathology 159: 247-254. https://doi.org/10.1111/j.14390434.2010.01758.x

Myers, R.M., Fischer, S.G., Lerman, L.S. and Maniatis, T., 1985. Nearly all single base substitutions in DNA fragments joined to a GC-clamp can be detected by denaturing gradient gel electrophoresis. Nucleic Acids Research 13: 3131-3145. https://doi.org/10.1093/nar/13.9.3131

Negedu, A., Atawodi, S.E., Baba, A., Umoh, V.J. and Tanko, 2011. Economic and health perspectives of mycotoxins: a review. Continental Journal of Biomedical Sciences 5: 5-26.

Niessen, L., 2007. PCR-based diagnosis and quantification of mycotoxin producing fungi. International Journal of Food Microbiology 119: 38-46. https://doi.org/10.1016/j.ijfoodmicro.2007.07.023

Olmos, A., Bertolini, E. and Cambra, M., 2002. Simultaneous and cooperational amplification (Co-PCR): a new concept for detection of plant viruses. Journal of Virological Methods 106: 51-59. https:// doi.org/10.1016/S0166-0934(02)00132-5
Parida, M., Sannarangaiah, S., Dash, P.K., Rao, P.V.L. and Morita, K., 2008. Loop mediated isothermal amplification (LAMP): a new generation of innovative gene amplification technique; perspectives in clinical diagnosis of infectious diseases. Reviews in Medical Virology 18: 407-421. https://doi.org/10.1002/rmv.593

Pereira, V.L., Fernandes, J.O. and Cunha, S.C., 2014. Mycotoxins in cereals and related foodstuffs: a review on occurrence and recent methods of analysis. Trends in Food Science and Technology 36: 96-136. https://doi.org/10.1016/j.tifs.2014.01.005

Porter-Jordan, K., Rosenberg, E.I., Keiser, J.F., Gross, J.D., Ross, A.M., Nasim, S. and Garrett, C.T., 1990. Nested polymerase chain reaction assay for the detection of cytomegalovirus overcomes false positives caused by contamination with fragmented DNA. Journal of Medical Virology 30: 85-91. https://doi.org/10.1002/jmv.1890300202

Priyanka, S.R., Mudili, D.V., Balakrishna, K.S., Murali, H. and Batra, H., 2015. Development and evaluation of a multiplex PCR assay for simultaneous detection of major mycotoxigenic fungi from cereals. Journal of Food Science and Technology 52: 486-492.

Raiola, A., Tenore, G.C., Manyes, L., Meca, G. and Ritieni, A., 2015. Risk analysis of main mycotoxins occurring in food for children: an overview. Food and Chemical Toxicology 84: 169-180. https:// doi.org/10.1016/j.fct.2015.08.023

Ramakrishna, R., Venakata Ramana, M., Ramlal, S., Uppalapati, S., Sripathy Murali, H. and Batra, H., 2012. Evaluation of a multiplex PCR assay for concurrent detection of four major mycotoxigenic fungi from foods. Journal of Applied Microbiology 114: 819-827. https://doi.org/10.1111/jam.12100

Rashmi, R., Ramana, M.V., Shylaja, R., Uppalapati, S.R., Murali, H.S. and Batra, H.V., 2013. Evaluation of a multiplex PCR assay for concurrent detection of four major mycotoxigenic fungi from foods. Journal of Applied Microbiology 114: 819-827. https://doi. org/10.1111/jam.12100

Reiter, E., Zentek, J. and Razzazi, E., 2009. Review on sample preparation strategies and methods used for the analysis of aflatoxins in food and feed. Molecular Nutrition and Food Research 53: 508524. https://doi.org/10.1002/mnfr.200800145

Richard, J.L., 2007. Some major mycotoxins and their mycotoxicoses an overview. International Journal of Food Microbiology 119: 3-10. https://doi.org/10.1016/j.ijfoodmicro.2007.07.019

Rossen, L., Nørskov, P., Holmstrøm, K. and Rasmussen, O.F., 1992. Inhibition of PCR by components of food samples, microbial diagnostic assays and DNA-extraction solutions. International Journal of Food Microbiology 17: 37-45. https://doi. org/10.1016/0168-1605(92)90017-W

Schena, L., Nigro, F., Ippolito, A. and Gallitelli, D.J.E.J.o.P.P., 2004. Real-time quantitative PCR: a new technology to detect and study phytopathogenic and antagonistic fungi. European Journal of Plant Pathology 110: 893-908. https://doi.org/10.1007/s10658-004-4842-9

Shephard, G.S., 2016. Current status of mycotoxin analysis: a critical review. Journal of AOAC International 99: 842-848. https://doi. org/10.5740/jaoacint.16-0111

Sheridan, G.E.C., Masters, C.I., Shallcross, J.A. and Mackey, B.M., 1998. Detection of mRNA by reverse transcription-PCR as an indicator of viability in Escherichia coli cells. Applied and Environmental Microbiology 64: 1313-1318. 
Somashekar, D., Rati, E.R. and Chandrashekar, A., 2004. PCRrestriction fragment length analysis of aflR gene for differentiation and detection of Aspergillus flavus and Aspergillus parasiticus in maize. International Journal of Food Microbiology 93: 101-107. https://doi.org/10.1016/j.ijfoodmicro.2003.10.011

Stackebrandt, E., Liesack, W. and Witt, D., 1992. Ribosomal RNA and rDNA sequence analyses. Gene 115: 255-260. https://doi. org/10.1016/0378-1119(92)90567-9

Stoev, S., 2013. Food safety and increasing hazard of mycotoxin occurrence in foods and feeds. Critical Reviews in Food Science and Nutrition 53: 887-901. https://doi.org/10.1080/10408398.20 11.571800

Streit, E., Schatzmayr, G., Tassis, P., Tzika, E., Marin, D., Taranu, I., Tabuc, C., Nicolau, A., Aprodu, I., Puel, O. and Oswald, I.P., 2012. Current situation of mycotoxin contamination and co-occurrence in animal feed - focus on Europe. Toxins 4: 788-809. https://doi. org/10.3390/toxins4100788

Susca, A., Proctor, R.H., Butchko, R.A.E., Haidukowski, M., Stea, G., Logrieco, A. and Moretti, A., 2014. Variation in the fumonisin biosynthetic gene cluster in fumonisin-producing and nonproducing black aspergilli. Fungal Genetics and Biology 73: 39-52. https://doi. org/10.1016/j.fgb.2014.09.009

Tannous, J., Atoui, A., El Khoury, A., Kantar, S., Chdid, N., Oswald, I.P., Puel, O. and Lteif, R., 2015. Development of a real-time PCR assay for Penicillium expansum quantification and patulin estimation in apples. Food Microbiology 50: 28-37. https://doi.org/10.1016/j. fm.2015.03.001

Tomita, N., Mori, Y., Kanda, H. and Notomi, T., 2008. Loop-mediated isothermal amplification (LAMP) of gene sequences and simple visual detection of products. Nature Protocols 3: 877-882. https:// doi.org/10.1038/nprot.2008.57
Turner, N.W., Bramhmbhatt, H., Szabo-Vezse, M., Poma, A., Coker, R. and Piletsky, S.A., 2015. Analytical methods for determination of mycotoxins: an update (2009-2014). Analytica Chimica Acta 901: 12-33. https://doi.org/10.1016/j.aca.2015.10.013

Upadhaya, S., Park, M.A. and Ha, J.-K., 2010. Mycotoxins and their biotransformation in the rumen: a review. Asian-Australasian Journal of Animal Sciences 23: 1250-1260. https://doi.org/10.5713/ ajas.2010.r.06

Walcott, R.R., Gitaitis, R.D. and Langston Jr., D.B., 2004. Detection of Botrytis aclada in onion seed using magnetic capture hybridization and the polymerase chain reaction. Seed Science and Technology 32: 425-438.

Wu, F., Groopman, J.D. and Pestka, J.J., 2014. Public health impacts of foodborne mycotoxins. Annual Review of Food Science and Technology 5: 351-372. https://doi.org/10.1146/annurevfood-030713-092431

Yamashita, S., Nakagawa, H., Sakaguchi, T., Arima, T.-H. and Kikoku, Y., 2018. Design of a species-specific PCR method for the detection of the heat-resistant fungi Talaromyces macrosporus and Talaromyces trachyspermus. Letters in Applied Microbiology 66: 86-92. https://doi.org/10.1111/lam.12818

Zain, M.E., 2011. Impact of mycotoxins on humans and animals. Journal of Saudi Chemical Society 15: 129-144. https://doi. org/10.1016/j.jscs.2010.06.006

Zhao, Y., Liu, N. and Niu, J.-X., 2009. A study of the distribution of apple stem pitting virus in tissues of pear tree using in situ hybridization and in situ RT-PCR. Agricultural Sciences in China 8: 1351-1359. https://doi.org/10.1016/S1671-2927(08)60347-8

Zhong, L., Carere, J., Lu, Z., Lu, F. and Zhou, T., 2018. Patulin in apples and apple-based food products: the burdens and the mitigation strategies. Toxins 10: 475. https://doi.org/10.3390/toxins10110475 